\title{
Богдан МАЛИНЯк
}

кандидат економічних наук, доцент, докторант, Західноукраїнський національний університет, Тернопіль, Україна, b.malyniak@wunu.edu.ua ORCID ID: 0000-0001-6965-393X

\section{ФУНКцї̈ ВИДАТКІВ БЮДЖЕТУ В ПУБАІЧНОМУ УПРАВАІННІ, ЕКОНОМІЧНІЙ I СОЦІАМЬНІЙ СИСТЕМАХ КРАЇНИ}

Вступ. Функції видатків бюджету розкривають їхнє призначення в регулюванні різноманітних процесів та пояснюють роль у досягненні визначених цілей. У наукових дослідженнях доволі розгорнуто представлено визначення функцій бюджету в країнах з ринковою економікою та демократичними відносинами в суспільстві, функціональне ж призначення видатків бюджету розкрито доволі фррагментарно.

Мета - науково обгрунтувати систему фрункцій видатків бюджету в країні з ринковою економікою та демократичними відносинами.

Результати. За результатами аналізу функцій видатків бюджету доцільно обгрунтовувати фрункиії окремо для двох основних сфер, на які бюджетні видатки справляють безпосередній вплив: публічне управління, а також економічну та соціальну системи країни. В публічному управлінні видатки бюджету реалізують функції планування (програмування) та контролю. Зміст фрункції планування (програмування) полягає в тому, що за допомогою видатків бюджету формують умови для раціонального планування діяльності органів публічного управління на основі результативних показників та їх досягнення в умовах застосування програмно-цільового методу бюджетування. Функція контролю полягає у забезпеченні контролю з боку громадськості за функціонуванням органів влади.

Вплив видатків бюджету на національну економіку та соціальну системи відбувається через фрункції розміщення, перерозподілу та стимулювання. Реалізація фрункції розміщення полягає в забезпеченні населення товарами та послугами, які не можуть бути надані ринковою економікою в необхідному обсязі. Сутність фрункції перерозподілу полягає в тому, щоб за допомогою видатків бюджету зменшувати нерівність у суспільстві. Функція видатків бюджету стимулювання полягає в тому, щоб, змінюючи обсяг, склад, структуру видатків бюджету, застосовуючи різні механізми їх здійснення, стимулювати певні напрямки економічної діяльності.

Висновки. За результатами дослідження теоретичних положень щодо функціонального призначення бюджету в країні з ринковою економікою та критичного аналізу наукових постулатів обгрунтовано доцільність виокремлення таких фрункцій видатків бюджету: планування (програмування), контролю, розміщення, перерозподілу та сти-

(с) Богдан Степанович Малиняк, 2021 
мулювання. Враховуючи їх відмінні властивості, доведено доцільність їх групування у дві групи: функції видатків бюджету в публічному управлінні та функції видатків бюджету в економічній і соціальній системах країни.

Ключові слова: бюджет, видатки бюджету, функції бюджету, фрункції видатків бюджету.

Рис.: 1, бібл.: 33.

\section{Богдан МАЛИНЯК}

кандидат экономических наук, доцент, докторант, Западноукраинский национальный университет, Тернополь, Украина

\section{ФУНКЦИИ РАСХОДОВ БЮДХЕТА В ПУБАИЧНОМ УПРАВАЕНИИ, ЭКОНОМИЧЕСКОЙ И СОЦИАМЫНОЙ СНСТЕМАХ СТРАНЫ}

Введение. Функции расходов бюджета раскрывают их значение в регулировании различных процессов и объясняют их роль в достижении определенных целей. В научных исследованиях довольно развернуто представлены определения фуункций бюджета в странах с рыночной экономикой и демократическими отношениями в обществе, функциональное же назначение расходов бюджета раскрыто довольно фрагментарно.

Цель - научно обосновать систему функций расходов бюджета в стране с рыночной экономикой и демократическими отношениями.

Результаты. По результатам анализа функций расходов бюджета целесообразно обосновывать фрункции отдельно для двух основных сфрер, на которые бюджетные расходы оказывают непосредственное влияние: публичное управление, а также экономическую и социальную системы страны. В публичном управлении расходы бюджета реализуют функции планирования (программирования) и контроля. Содержание функции планирования (программирования) заключается в том, что с помощью расходов бюджета фрормируют условия для рационального планирования деятельности органов публичного управления на основе результативных показателей и их достижения в условиях применения программно-целевого метода бюджетирования. Функция контроля заключается в обеспечении контроля со стороны общественности за функционированием органов власти.

Влияние расходов бюджета на национальную экономику и социальную системы происходит через фрункции размещения, перераспределения и стимулирования. Реализация фрункци размещения заключается в обеспечении населения товарами и услугами, которые не могут быть предоставлены рыночной экономикой в необходимом объеме. Сущность фрункции перераспределения заключается в том, чтобы с помощью расходов бюджета уменьшать неравенство в обществе. Функция расходов бюджета стимулирования заключается в том, чтобы, изменяя объем, состав, структуру расходов бюджета, применяя различные механизмы их осуществления, стимулировать определенные направления экономической деятельности.

Выводы. По результатам исследования теоретических положений относительно функционального назначения бюджета в стране с рыночной экономикой и критического анализа научных постулатов обоснована целесообразность выделения таких фрукций расходов бюджета: планирования (программирования), контроля, размещения, перераспределения и стимулирования. Учитывая их отличительные свойства, доказана целесо- 
образность их группировки в две группы: функции расходов бюджета в публичном управлении и фуункци расходов бюджета в экономической и социальной системах страны.

Ключевые слова: бюджет, расходы бюджета, фрункции бюджета, фрункции расходов бюджета.

\section{Bohdan MALYNIAK}

Ph. D. (Economics), Assoc. Prof., West Ukrainian National Economic University, Ternopil, Ukraine, e-mail: b.malyniak@wunu.edu.ua

ORCID ID: 0000-0001-6965-393X

\section{THE FUNCTIONS OF PUBLIC EXPENDITURES IN PUBLIC MANAGEMENT, ECONOMIC AND SOCIAL SYSTEMS OF A COUNTRY}

Introduction. The functions of public expenditures reveal their intended purpose in the regulation of various processes and explain their role in the attainment of specific goals. Scientific literature provides extensive insights into definitions of budget functions in market democracies, but the functional purpose of public expenditures is covered only fragmentarily.

The purpose of the article is to present a scientific substantiation for the system of public expenditure functions in the market democracies.

Results. Based on the analysis of public expenditure functions, we believe that it would be feasible to substantiate the functions separately for each of the two main spheres directly affected by public expenditures, namely public management and the economic and social system of the country. In the public management sphere, public expenditures perform the functions of control and planning (programming). The essence of the planning function consists in using public expenditures to create conditions and provide necessary incentives for rational performance-based planning of the activities carried out by public authorities, as well as for attainment of target performance indicators by applying the results-oriented budgeting method. The function of control is preconditioned by the specifics of public management system functioning in a democratic society, which consists in assuring that the society has control over activities of public authorities.

The influence of public expenditures on the national economy and its social system occurs through functions of allocation, redistribution and stimulation. The function of allocation consists in providing the population with goods and services that cannot be supplied by the market economy in sufficient volumes. The essence of the redistribution function consists in using public expenditures with the aim of decreasing income inequality among members of the society, regional development of territories or solving other tasks. The public expenditure function of stimulation aims to stimulate certain directions of economic activity by means of changing the volumes, components or structure of public expenditures through different mechanisms of their realization.

Conclusions. In result of performing a theoretical study of the functional purpose of the budget in a market economy and a critical analysis of scientific postulates allow us to substantiate the feasibility of identifying the following functions of public expenditures: planning (programming), control, allocation, redistribution, and stimulation.

Keywords: budget, public expenditures, budget functions, public expenditure functions..

JEL Classification: $\mathrm{H} 60$. 
Постановка проблеми. Цілі видатків бюджету обґрунтовують їхнім функціональним призначенням. Видаткам бюджету властиве виконання не лише загальних функцій бюджету, а й притаманні їм певні специфічні властивості. Розуміння функцій видатків бюджету в країні з ринковою економікою та демократичними відносинами в суспільстві дає змогу формувати раціональні пріоритети у витрачанні бюджетних коштів з урахуванням наявних умов. Це слугує також запорукою ефективного використання коштів бюджету та необхідною умовою для досягнення визначених завдань бюджетної політики. Розвиток вчення про бюджет, застосування сучасних методів управління бюджетними ресурсами, радикальна трансформація економічних умов та суспільних відносин ставлять нові завдання перед суб'єктами управління бюджетними видатками. У зв'язку з цим важливо розуміти вектори розвитку функцій видатків бюджету, особливості взаємодії між ними та їхні сучасні характеристики.

Аналіз останніх досліджень і публікацій. Функціональне призначення видатків бюджету $€$ одним з основних питань, якому приділяють увагу провідні науковці та фахівці-практики. Дослідження функцій бюджетних видатків відбувалося в контексті осмислення ролі держави в регулюванні економічних процесів та соціальної сфери, а також теоретичного обґрунтування функцій суспільних фрінансів. Сучасне розуміння функціонального призначення бюджету сформувалося у фрінансовій науці в 20 столітті. Значний внесок у систематизацію функцій суспільних фрінансів здійснили Р. Масгрейв та П. Масгрейв. У класичній праці “Суспільні фінанси: теорія та практика” вчені запропонували трактувати роль бюджету в ринковій економіці крізь призму трьох функцій: 1) аллокаційної - державного забезпечення товарами і послугами, котрі належать до суспільних благ; 2) дистрибуційної - вплив на структуру розподілу і багатства; 3) стабілізаційної - заходи, які застосовують для боротьби з безробіттям, інфляцією та неадекватним економічним зростанням [1, с. 21-30]. Сфрормульовані в середині 20 століття видатними вченими фрункції стали фундаментальними для розвитку вчення про призначення бюджету та залишаються актуальними. Вчення про функції суспільних фрінансів, яке розвинулося на базі ідей Р. Масгрейва та П. Масгрейва, для західної фрінансової науки набуло традиційних рис та увійшло до найпопулярніших підручників у сфері суспільних фрінансів. Справді, пояснення логіки фіскальної діяльності держави та управління бюджетними ресурсами реалізацією зазначених трьох функцій обґрунтоване та сприяє системному розумінню природи певних видатків бюджету. На нашу думку, практичне застосування описаних вченими функцій може викликати труднощі, оскільки нерідко певним видаткам бюджету властиві ознаки декількох функцій одночасно.

Цікаве і водночас доволі зрозуміле пояснення функцій бюджету розробив М. Волкер. Для цього вчений застосував постулати теорії граничної корисності. Відтак він стверджував, що основна функція бюджету зводиться до досягнення бюджетної рівноваги за допомогою максимізації граничної корисності держави (яка складається з членів уряду та інших членів суспільства). Розвиваючи цю ідею, вчений розкрив способи досягнення такої рівноваги через удосконалення надання суспільних послуг, захист супільства та зростання добробуту [2].

У фрінансовій науці вирішення проблеми певної абстрактності запропонованих Р. Масгрейвом та П. Масгрейвом функцій бюджету відбувалося шляхом детального обґрунтування та пояснення кожної з них. М. Хакбарт і Дж. Рамсей погоджували- 
ся з тим, що бюджет виконує алокаційну, дистрибутивну та стабілізаційну функції. Функціональна роль алокаційної функції бюджету, на думку згаданих вчених, спрямовувалася на вирішення завдань, зумовлених наявністю: 1) товарів чи послуг суспільного або колективного споживання; 2) зовнішніх ефектів; 3) природних монополій або недосконалої конкуренції; 4) споживчої необізнаності [3, р. 174-175].

Призначення ж дистрибутивної функції бюджету М. Хакбарт та Дж. Рамсей вбачали у реалізації заходів щодо перерозподілу ресурсів з метою досягнення Парето-ефективності, адже вони розуміли, що корекцією ринків у межах реалізації лише алокаційної функції цього досягти не вдасться. Звертає на себе увагу пояснення вчених щодо призначення стабілізаційної функції бюджету. Так, вони вважали, що алокаційна та дистрибуційна функції зосереджені на вирішенні мікроекономічних завдань, а стабілізаційна - на усуненні макроекономічних проблем, а саме безробіття, інфляції та економічного зростання [3, p. 181-182]. 3 такою позицією вчених важко погодитися, адже, на наше переконання, кожна з описаних функцій бюджету проявляється як на макро-, так і на мікроекономічному рівнях.

Схожий підхід до з'ясування функцій бюджету застосував Дж. Стігліц. Обґрунтовуючи необхідність державного втручання в ринкову економіку, в тому числі за допомогою бюджету, вчений наводив дві групи обставин: 1) пов'язані з ринковими невдачами; 2) зумовлені необхідністю перерозподілу та потрібних товарів [4, с. 103-117]. Першу групу обставин, які обґрунтовують функціональне призначення суспільних фінансів, складають: неефективність конкуренції; товари суспільного споживання; екстерналії; неповні ринки; недостовірність інформації; безробіття, інфляція і дисбаланс. Запропонований вченим підхід збагатив фінансову науку трактуванням функціонального призначення видатків бюджету. Слабким місцем позиції Дж. Стігліца щодо обґрунтування функціонального призначення бюджету, на наш погляд, $є$ об'єднання до однієї групи дуже неоднорідних чинників, що потребують відмінного застосування бюджетного інструментарію.

Запропонований Ш. Бланкартом перелік функцій бюджету має чітко виражений прикладний характер. Вчений наділяє бюджет різними функціями залежно від того, розглядається бюджет з позиції парламенту чи уряду [5, с. 448-449]. 3 позиції парламенту, на думку вченого, найважливішою функцією бюджету є контрольна, її суть зводиться до права представницького органу визначати ключові параметри бюджету на визначений період, тим самим визначаючи обмеження для урядової діяльності. Водночас з позиції уряду реалізується функція планування, яка передбачає встановлення складу та структури видатків бюджету. Оригінальний підхід до трактування функцій бюджету сприяє розумінню природи видатків бюджету та розвитку вчення про управління бюджетом. Обмеження згаданої позиції Ш. Бланкарта, на нашу думку, полягає в тому, що вчений запропонував лише головні функції бюджету з позиції ключових суб'єктів бюджетного менеджменту, при цьому не навів переліку функцій як цілісної системи.

Ідея прикладного застосування науково обґрунтованих функцій видатків бюджету розвинута сучасними дослідниками суспільних фрінансів. В. Доротинський наводить три функції видатків бюджету: контроль, програмування та управління [6]. Вчений наголошує, що запропонований склад функцій $є$ спрощеним і спрямований на фокусування уваги на ключових характеристиках бюджетних видатків. При цьому зроблено спробу гармонізувати функції видатків бюджету з функціями доходів, а 
саме: реалізація функції видатків контролю узгоджена з функцією доходів достовірного прогнозування; фрункція видатків програмування - з функцією доходів забезпечення справедливості та оптимального рівня оподаткування; функція видатків управління з функцією доходів фіскального адміністрування. Важливо зауважити, що ключовою метою реалізації функцій вчений визначив досягнення фріскальної стабільності в країні. При цьому він наголошує на важливості поєднання усіх наведених функцій видатків бюджету, адже механічного обмеження видатків за принципом “зверху-вниз" за допомогою контрольної функції недостатньо для належного управління видатками бюджету. Відтак реалізація функції видатків програмування та управління спроможна забезпечити належний розподіл ресурсів та їх ефективне використання.

Зазначене дослідження функцій видатків бюджету, на наш погляд, є важливим кроком у розумінні призначення суспільних видатків та розбудови інституційного середовища їх застосування. Аргументи на користь поєднання усіх функцій фрінансів та обґрунтування системного підходу до трактування функцій видатків та доходів сприяють системному розкриттю функціонального призначення видатків бюджету. Разом з тим, тлумачення функцій видатків бюджету не розкриває окремі важливі аспекти бюджетних видатків, що пояснюють їх сенс, а більше зорієнтоване на пояснення управлінських засад процесу формування та здійснення видатків.

Схоже бачення призначення бюджетних видатків обґрунтовано в працях Е. Кампос та С. Фадан. Функціональні цілі управління бюджетними видатками, на їхню думку, мають передбачати забезпечення: фіскальної дисципліни (контроль витрат); розподіл ресурсів відповідно до пріоритетів політики (“стратегічний” розподіл”) та хоро- ше оперативне управління [7]. Зосередившись на дослідженні архітектури управління суспільними фінансами, вченим вдалося успішно розкрити функції видатків бюджету з позиції організації публічного управління в країні з ринковою економікою та демократичними відносинами. На наш погляд, визначені авторами дослідження фрункції видатків бюджету не розкривають їх змісту, а радше визначають загальні напрямки.

Проведений огляд результатів дослідження функцій видатків бюджету представниками західної фрінансової думки засвідчив багату палітру поглядів. Вчені сміливо обґрунтовують ідеї, які розвивають погляди їхніх колег або мають певні протиріччя. Результатом такої дискусії стала кристалізація трактування функцій бюджету в контексті двох сфер, на який мають вплив суспільні фінанси: 1) загального функціонального призначення видатків у вирішенні соціальних та економічних завдань розвитку країни чи органу місцевого самоврядування; 2) застосування видатків бюджету як елемента публічного управління спроможного слугувати засобом досягнення суспільно важливих цілей. Обидва згаданих контексти насправді $€$ дуже важливими, вони абсолютно не заперечують один одного, а, на наше переконання, навпаки - доповнюють один одного.

Дослідження ж фрункцій видатків бюджету українськими фрінансистами та їхніми колегами з пострадянських країн менш різнобарвні та більше корелюють між собою. Втім дослідження цього доробку для формування розуміння функцій видатків бюджету $є$ не менш корисним, ніж праці представників західної фрінансової науки, адже вони враховують специфічні умови функціонування суспільних фрінансів у посттоталітарних країнах, сформований інституційний механізм управління бюджетом та їхню інтерпретацію в наукових дослідженнях. 
Крім цього, на прикладі дослідження функціонального призначення видатків бюджету можна зрозуміти еволюцію вчення про видатки бюджету та логіку теоретичного обґрунтування їхньої природи.

У наукових дослідженнях вчені зазвичай досліджують функції бюджету без виокремлення вивчення фуннкцій бюджетних видатків. У таких умовах розуміння функції видатків бюджету формується за результатами аналізу змісту функціонального призначення бюджету загалом. Це свідчить, зокрема, й про те, що проблематика бюджетних видатків залишається не повністю дослідженою.

У науковій літературі часто вчені зупиняються на обґрунтуванні двох функцій бюджету. Так, О. Романенко описує розподільчу та контрольну функції бюджету. При цьому вчений зазначає, що бюджет в основному відображає вторинний перерозподіл, у процесі якого за участю видатків відбувається надання благ і послуг. Контрольна функція дає змогу дізнатися, наскільки та як складаються пропорції у розподілі бюджетних коштів, чи ефективно їх використовують [8, с. 147]. Ці ж функції бюджету обґрунтовують у своєму дослідженні Р. Ісламгулов [9, с. 7], М. Корягін [10, с. 205], Ю. Пасічник [11, с. 272-273], В. Родіонова, Ю. Вавилов, Л. Гончаренко [12, с. 235], І. Розпутенко [13, с. 83] та ін. Варто зазначити, що попри те, що згадані вчені дотримуються думки про доцільність фокусування уваги на двох функціях бюджету розподільчої та контрольної, вони зазвичай по-різному тлумачать їх змісту. Так, роль видатків у реалізації розподільчої функції бюджету зазвичай зводиться до коригування суспільного виробництва шляхом фінансування суспільних благ, а також надання трансфертів економічним суб'єктам. Місце видатків у реалізації контрольної функції бюджету вчені часто пояснюють як можли- вість мати повну інформацію про параметри самого бюджету. На наш погляд, поширене фрормулювання розподільчої фрункції бюджету радше розкриває механізм впливу бюджету на соціально-економічні процеси, ніж пояснює сенс такої діяльності, її мету. Нерідко тлумачення контрольної функції бюджету полягає у можливості контролю за формуванням та використанням бюджетних коштів, тобто звернена на забезпечення можливості функціонування бюджетного механізму. Поділяємо думку К. Павлюк, що такі формулювання контрольної фрункції бюджету не виражають його суспільного призначення [14, с. 36].

Розвиток дискусії щодо функцій бюджету здебільшого передбачав розширення складу функцій бюджету. Втім окремі науковці відстоюють позицію про те, що бюджету властива єдина функція. Прикладом такого підходу $€$ дослідження Н. Савчук щодо доцільності обґрунтування лише перерозподільної функції, яка включає алокаційну та стабілізаційну підфункції [15, c. 57-58]. 3 таким баченням доволі складно погодитися, адже багатоаспектний вплив на економічний і соціальний розвиток бюджету є беззаперечним. До того ж такий вплив досягається за допомогою різноманітних інструментів, в тому числі витрачання бюджетних коштів. Це обґрунтовує об'єктивну потребу в з'ясуванні однорідних за своїми властивостями ознак бюджетних видатків, які розкривають такий вплив.

Доволі популярний шлях розвитку вчення про фрункції видатків бюджету полягав у доповненні розподільчої та контрольної функцій бюджету третьою функцією - забезпечення існування держави. Таку думку поділяли, зокрема, С. Булгакова [16, с. 35], К. Захожай [17, с. 18], М. Деркач, Л. Гордєєва [18, с. 18-20]. Доволі спірним у запропонованій конструкції, на нашу думку, є виокремлення в окремий напрям функції за- 
безпечення існування держави. Зазначене формулювання функції бюджету схиляє до думки, що інші функції бюджету не пов'язані з реалізацією функції держави. Втім з цим погодитися дуже складно, адже як розподіл ресурсів, так і реалізація контролю безпосередньо пов'язані з функціями держави чи органу місцевого самоврядування.

А. Чухно наводить аргументи на користь виокремлення ще й гуманітарно-соціальної функції [19, с. 161]. На думку вченого, саме ця функція створює умови для відтворення і розвитку людського капіталу. Дотримується цієї думки О. Гордей, яка наводить аргументи щодо виокремлення соціальної функції бюджету [20, С. 195]. На наш погляд, акцентування уваги на соціальній ролі бюджету є позитивним напрямком, однак, враховуючи те, що різні складові певного явища мають доповнювати один одного, запропонована вченими соціальна функція фрактично дублює описану ними ж розподільчу функцію.

Свій вклад у наукове пізнання функцій бюджету зробив С. Юрій, який наполягав на доцільності виокремлення чотирьох функцій бюджету: розподільчій, контрольній, регулюючій та стимулюючій [21, с. 8]. При цьому стверджував, що зміст функцій, їхня спрямованість, характер реалізації залежить від особливостей економічних процесів у країні. Складність застосування запропонованих функцій полягає в дуже тонкій грані між змістом регулюючої та стимулюючої функції. Схожі проблеми притаманні також запропонованому Ф. Ярошенком складу функцій бюджету: акумуляційна, регулятивна, стимулююча, перерозподільна та контрольна [22, с. 5-7]. Я. Жаліло розвиває тлумачення функцій бюджету та обґрунтовує фріскальну, регулюючу, стратегічну структурну та стимулюючу функції [23, с. 293]. Реалізація структурної та стимулюючої функцій надає бюджетному процесу властивостей стратегії, тому саме завдяки їм має забезпечуватися ефективність бюджетної політики в країні. Втім, на нашу думку, важко окреслити чіткі грані для великої кількості наведених вченими функцій бюджету.

О. Ніколаєва, А. Маглаперідзе - одні $з$ небагатьох українських вчених, які навели перелік фрункцій видатків бюджету: стабілізаційна, розподільна, алокаційна, інформаційна, інституціональна, регулювальна, стимуляційна, контрольна [24, с. 135]. У цьому переліку не складно помітити такі, які значною мірою дублюють одна іншу (як от розподільна та алокаційна; регулювальна та стимуляційна), а також такі, дія яких поглинає декілька інших (наприклад, інституціональна, яка поширюється на інші функції).

Оригінальний підхід до систематизації функцій бюджету запропонував О. Уманець. У дослідженні вчений обґрунтував 10 функцій бюджету та закріпив їх за трьома частинами бюджетних відносин:

- дохідна частина (фріскальна функція);

- організаційна частина (планова, розподільча, контрольна, інформаційна);

- видаткова часина (відновлювальна, регулююча, стимулююча, соціальна, міжнародна) [25, с. 27].

У наукових публікаціях подано різноманітні погляди на склад функцій видатків бюджету та їхній зміст. Здебільшого системно відображено функції бюджету загалом, натомість функціональне призначення видатків бюджету розкрито доволі фррагментарно і переважно представниками західної фрінансової думки. Зокрема, не розкрито цілісну систему функцій видатків бюджету, які вони виконують в регулюванні економічних та соціальних процесів у тій чи іншій країні.

Метою публікації $€$ наукове обґрунтування системи функцій видатків бюджету в країні з ринковою економікою та демократичними відносинами. 
Виклад основного матеріалу дослідження. Природа певних явищ і процесів часто виявляється у тих функціях, які вони виконують в економічній системі та соціальному середовищі. Дефініція “функція” (від лат. function - виконання, завершення) застосовується у кількох значеннях. Словник іншомовних слів наводить три тлумачення цього слова: 1) діяльність, обов'язок, робота; призначення; 2) величина, яка змінюється зі зміною незалежної змінної величини (математика); 3) специфічна діяльність органа чи організму (біологія) [26, с. 630]. Академічний тлумачний словник української мови пропонує схоже визначення слова "функція": 1) явище, яке залежить від іншого явища, $є$ формою його виявлення і змінюється відповідно до його змін; робота кого-, чого-небудь, обов'язок, коло діяльності когось; 2) призначення, роль чого-небудь; 3) специфічна діяльність організму людини, тварин, рослин, їхніх органів, тканин і клітин; 4) величина, яка змінюється зі зміною незалежної змінної величини (аргументу) [27].

В оксфордському словнику наведено схоже пояснення слова "functionen": 1) особлива діяльність або призначення людини чи речі; 2) соціальна подія або офіційна церемонія; 3) величина, значення якої залежить від різних значень інших; 4) частина програми тощо, яка виконує базову операцію [28]. Одне з семантичних значень слова "функція" позначає призначення чогось, його роль у чомусь. Саме в такому контексті його використовують у дослідженнях економічних явищ та процесів. Так, в економічному словнику функції тлумачать, зокрема, як діяльність, зобов'язання, роботу, а також як зовнішній прояв властивостей якого-небудь об'єкта в певній системі відносин [29].

3 огляду на це, функції видатків бюджету відображають узагальнене вираження певної сукупності процесів та економічних відносин щодо розподілу та використання фінансових ресурсів, які здійснюють від імені народу органи державного управління та місцевого самоврядування. Функції видатків бюджету мають підпорядковуватися єдиній меті, при цьому впливати на певні соціально-економічні процеси та відігравати важливу роль у розвитку суспільства, в тому числі через застосування різних видів економічної та соціальної діяльності. Варто зазначити, що використання коштів бюджету передбачає застосування відмінних підходів до надання бюджетних ресурсів, формування складу суб'єктів, наділених правами використання коштів бюджету, різних правил їх використання та звітування тощо. Це безпосередньо впливатиме на наслідки реалізації функцій видатків бюджету для різних сфер життєдіяльності економічної системи, суспільних відносин, міжнародної політики тощо.

За результатами аналізу функцій видатків бюджету вважаємо, що доцільно обґрунтовувати функції окремо для двох основних сфер, на які бюджетні видатки справляють безпосередній вплив: публічне управління, а також економічну та соціальну системи країни. В публічному управлінні видатки бюджету реалізують функції контролю та планування (програмування) (рис. 1). Вплив видатків бюджету на національну економіку та соціальну систему відбувається через функції розміщення, перерозподілу та стимулювання.

Безпосередній стосунок до формування та використання коштів бюджету мають органи публічного управління. Бюджет $€$ не лише продуктом діяльності влади, а й інструментом, за допомогою якого здійснюється вплив на різні суб'єкти публічного управління. Наявність великого впливу видатків бюджету на фрункціонування органів публічної влади та природу самого впливу, 


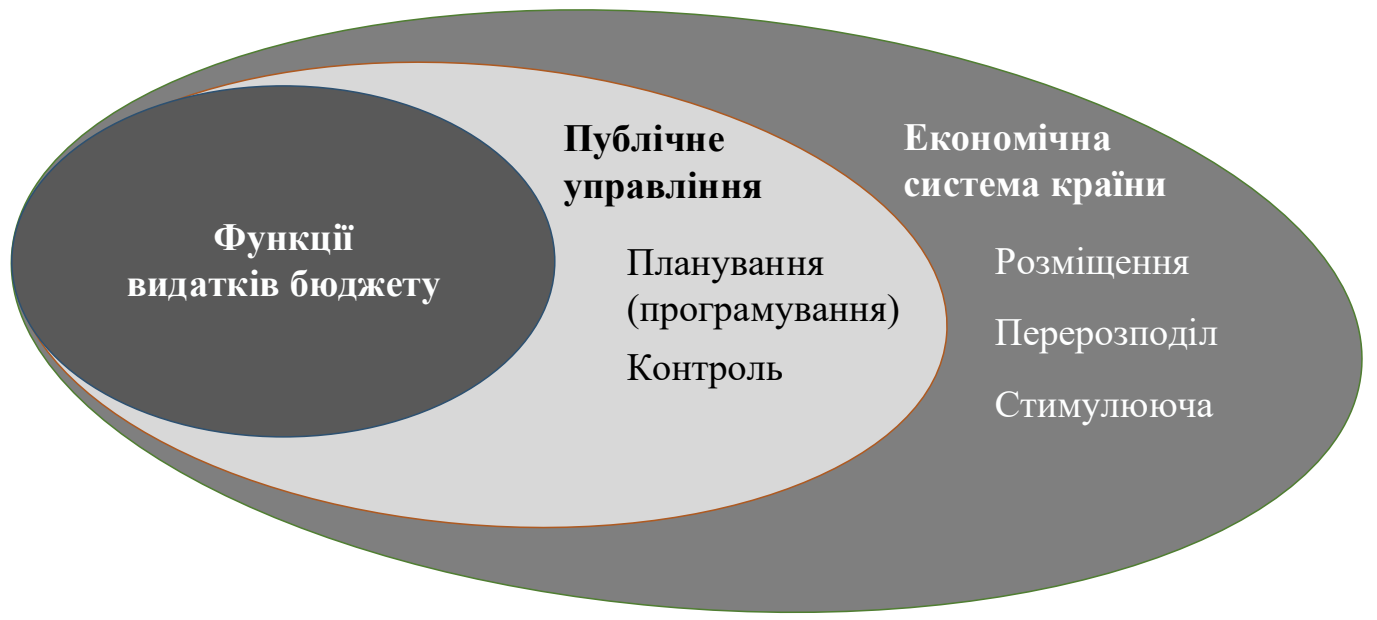

Рис. 1. Функції видатків бюджету в публічному управлінні та в економічній і соціальній системах країни

слугувало обґрунтуванням необхідності виокремлення двох функцій видатків бюджету в царині публічного управління: планування (програмування) та контроль.

Еволюція концепції бюджетного менеджменту свідчить про активне запровадження методів управління фінансовими ресурсами з реального сектору економіки до публічного, в основі яких було покладено можливість керування результатами за допомогою виокремлення певних фінансових ресурсів. Таким чином у сферу суспільних фінансів було запроваджено концепцію програмно-цільового бюджетування. Ії застосування передбачає узгодження фрінансування суб'єктів державного сектору з результатами, які вони забезпечують на основі систематичного використання інформації про результативність з метою підвищення ефективності та результативності державних видатків [30, 2]. Саме видатки бюджету $€$ головним інструментом реалізації програмно-цільового бюджетування (або бюджетування, орієнтованого на результат). В умовах застосування програмно-цільового методу бюджетування за допомогою використання видатків бюджету забезпечують умови та створюють необхідні стимули для раціонального планування діяльності органів публічного управління на основі результативних показників та їх досягнення.

Впродовж всього етапу історії держави, бюджет слугував засобом забезпечення діяльності владних інституцій. Саме тому видатки бюджету $є$ також засобом забезпечення операційної діяльності установ публічного сектору економіки. Таким чином, за допомогою видатків бюджету можна мати докладну інформацію про діяльність суб'єктів державного управління та місцевого самоврядування. Функція контролю зумовлена особливістю функціонування системи публічного управління в демократичному суспільстві, яка полягає у забезпеченні контролю, насамперед, з боку громадськості за функціонуванням органів влади. Крім цього, фрункція контролю пов'язана із взаємодією різних гілок та рівнів влади всередині країни, організацією відносин в межах організаційної структури окремих суб'єктів публічного управління, а також ді- 
яльністю держави на міжнародному рівні. Таким чином, контрольна функція видатків бюджету виявляється у кількох вимірах:

- міжнародний - контроль міжнародного співтовариства за виконанням окремими країнами (групами країн) взятих на себе зобов'язань (наприклад, у сферах екології, безпеки, оборони, боротьби з епідеміями), моніторинг діяльності окремих національних урядів з використанням аналізу та оцінювання видатків бюджету;

- національний (регіональний, місцевий) - контроль громадянського суспільства за діяльністю органів публічного управління із застосуванням аналізу та оцінювання видатків бюджету;

- між гілками влади - контроль за діяльністю з боку парламенту через встановлення обмежень на здійснення видатків бюджету для учасників бюджетного процесу;

- між різними ланками публічного управління - органами державного управління та органами місцевого самоврядування;

- адміністративний - контроль головними розпорядниками бюджетних коштів та розпорядниками бюджетних коштів вищого рівня за діяльністю розпорядників (одержувачів) бюджетних коштів нижчого рівня.

Видатки бюджету слугують важливим інструментом забезпечення суспільних потреб та регулювання економічних процесів. 3 урахуванням результатів дослідження функціонального призначення бюджету та його видатків, вважаємо, що основними функціями видатків бюджету в економічній системі країни є: розміщення, перерозподіл та стимулювання (рис. 1).

Реалізація функції розміщення полягає у забезпеченні населення товарами та послугами, які не можуть бути надані ринковою економікою в необхідному обся- зі. Варто зазначити, що в населення існує потреба в чистих суспільних благах, які в звичайних умовах не надають суб'єкти реального сектору економіки. Характерними властивостями чистих суспільних благ є: по-перше, неможливість виключення окремого споживача від їх споживання, або наявність значних витрат, пов'язаних з таким виключенням; по-друге, надання послуги додатковому споживачу не збільшує витрати. Добровільне об'єднання громадян з метою фінансового забезпечення таких благ практично неможливе: завжди виявляться особи, які не бажатимуть брати участь у їх фінансуванні, однак відлучити їх від користування послугами буде неможливо. Відтак, єдиним джерелом забезпечення цих послуг є видатки бюджету.

За рахунок бюджетних коштів забезпечується надання не лише суто суспільних благ, а й інших, які мають ознаки приватних. У випадку самостійного прийняття приватними особами рішень щодо придбання певних послуг, вигоди від їх отримання можуть бути оцінені необ'єктивно. Це може призвести до того, що обсяги виробництва та споживання благ, які мають неабияку суспільну значущість, будуть недостатніми. Тому вважається, що в окремих випадках інтереси громадян відомі державі краще, ніж приватним особам, і широкий спектр видатків має здійснювати безпосередньо держава [4, с. 114].

Сутність функції перерозподілу полягає в тому, щоб за допомогою видатків бюджету, зокрема надання трансфертів населенню, адміністративно-територіальним одиницям, міжнародним суб'єктам, можна досягти зменшення нерівності доходів членів суспільства, територіальних дисбалансів чи вирішення інших завдань. Видатки бюджету для перерозподілу застосовують, зокрема, з метою недопущення істотних відмінностей між особами з низькими та ви- 
сокими статками, зниження рівня бідності, вони є одним із засобів досягнення гармонії та справедливості в суспільстві. Наявність соціальної допомоги в умовах демократії свідчить про те, що становище нужденних небайдуже основній масі податкоплатників [31, с. 275].

Роль функції стимулювання полягає в тому, щоб, змінюючи обсяг, склад, структуру видатків бюджету, застосовуючи різні механізми їх здійснення, стимулювати певні напрямки економічної діяльності, чим досягати зменшення негативних наслідків амплітуди економічних циклів та усунення проблем в економічній системі. Загалом же помірне збільшення бюджетних видатків в період спаду економіки стимулює сукупний попит, що позитивно впливає на динаміку економічних індикаторів. Окрім цього, спрямування видатків на секторальну підтримку окремих галузей економіки чи важливих кластерів має на них стимулюючий вплив.

Запропонований підхід до обґрунтування функцій бюджету враховує всі ключові аспекти впливу видатків бюджету на соціальний та економічний розвиток, забезпечуючи диференційований підхід для з'ясування різнопланової ролі бюджетних видатків в економічній системі. Важливо зауважити, що видатки бюджету часто забезпечують реалізацію не лише однієї функції, а й комбіноване виконання двох функцій, або - навіть усіх трьох. При цьому варто розуміти головний сенс здійснення тих чи інших видатків, який виявляється в реалізації однієї функції видатків бюджету, та додаткові ефекти від таких видатків, що мають наслідки для реалізації інших функцій видатків бюджету.

Теоретичне обґрунтування визначених трьох функцій бюджету в економічній та соціальній системах країни дає змогу також сорормувати концептуальне бачення розмежування видатків між різними ланками бюджетів у складі бюджетної системи країни. Функція розміщення, яка передбачає забезпечення населення та економічних суб'єктів суспільними благами, може здійснюватися за рахунок видатків як державного, так і місцевих бюджетів. Тому важливою $є$ проблема розподілу повноважень на здійснення видатків між різними рівнями бюджетів. Основний принцип розмежування видаткових зобов'язань між центральною владою та місцевим самоврядуванням був сформульований ще в середині XVIII століття А. Смітом. Вчений зазначав: “витрати, що мають місцеве чи регіональне значення, мають покриватися з місцевих чи регіональних доходів і не обтяжувати собою загальний дохід суспільства. Несправедливо, аби суспільство в цілому давало кошти на оплату витрат, здійснених на користь лише однієї частини цього суспільства" [32, с. 499].

Наприкінці XX століття американський вчений Р. Масґрейв, підтверджуючи вірність запропонованого принципу, зауважив: "забезпечення суспільних послуг має визначатися і оплачуватися тими, хто отримує від них вигоду. Суспільні блага і послуги, користь від яких мають все населення країни, має забезпечуватися і оплачуватися централізовано, тоді як ті, що поширюються тільки на якийсь певний регіон, - на місцевому рівні" [33, с. 105]. Вирішуючи питання забезпечення суспільних послуг за рахунок бюджетних коштів, слід мати на увазі, що при децентралізованому підході існує можливість повніше враховувати інтереси споживачів, а при переході до централізованого забезпечення - знизити вартість послуг.

Здійснення же перерозподільних заходів на місцевому рівні може бути пов'язане з виникненням додаткових стимулів для міграції громадян з однієї місцевості до іншої. Окремі особи, переважно найбідніші, намагатимуться обрати для проживання ті регіони, де надають більші обсяги транс- 
фертів населенню. Уникнути цього явища можна завдяки встановленню загальнонаціональних параметрів бюджетних видатків, які спрямовують на здійснення перерозподільних заходів. Разом з тим, місцева влада оперує більш повною і достовірною інформацією про фрінансове і майнове становище мешканців території, що свідчить на користь здійснення таких видатків місцевих бюджетів.

Можливість реалізації функції стимулювання на місцевому рівні в умовах відкритості регіональних економік $\epsilon$ доволі обмеженою. Адже коли відбувається вільний рух товарів, капіталу та робочої сили в межах усієї країни, стимулювання економічного зростання на певній території пошириться на економіку інших регіонів, що значно послабить вплив місцевої бюджетної політики. Пожвавлення економічної системи держави за допомогою видатків бюджету ефективне за умови узгодження фріскальної і грошово-кредитної політики. Якщо в країні існує єдина грошово-кредитна система, а місцеві економіки відкриті одна для іншої, реалізація функції стимулювання за допомогою видатків місцевих бюджетів буде неефективною. Тому такі видатки доцільно закріпити за державним бюджетом. Ефективність видатків місцевих бюджетів, спрямованих на стимулювання економічного розвитку, є меншою ще й тому, що в період економічного спаду відбувається скорочення надходжень цих бюджетів одночасно зі зростанням частки видатків соціального призначення. В цих умовах обмежені можливості дохідної бази місцевого самоврядування не дають змоги збільшувати необхідні видатки з метою стабілізації й покращення економічної ситуації.

Спрямування видатків бюджету на певні цілі зазвичай передбачає реалізацію кількох функцій. У можливих комбінаціях беруть участь як функції у сфрері публічно- го управління, так і функції в економічній та соціальній системах країни. Розуміння усіх можливих наслідків використання бюджетних коштів створює передумови для оцінювання ефективності видатків.

Функції видатків бюджету, які згруповані у дві групи, перебувають у безпосередній залежності від чинників, які впливають на бюджетну політику. Так, екзогенні чинники, що діють на видатки бюджету (наприклад, суспільні запити, можливості національної економіки, природа науково-технічного прогресу, вплив міжнародних відносин тощо) спонукають відповідні суб'єкти до активізації тих чи інших функцій бюджетних видатків в економічній та соціальній системах. Ендогенні чинники видатків бюджету (бюджетний менеджмент, корупція, організація міжбюджетних відносин) перебувають у взаємній залежності з функціями видатків бюджету в публічному управлінні.

Висновки. За результатами дослідження теоретичних положень щодо функціонального призначення бюджету в країні $з$ ринковою економікою та критичного аналізу наукових постулатів обґрунтовано доцільність виокремлення таких функцій видатків бюджету: планування (програмування), контроль, розміщення, перерозподіл та стимулювання. Враховуючи їх відмінні властивості, доведено доцільність їх групування у дві групи: функції видатків бюджету в публічному управлінні та функції видатків бюджету в економічній і соціальній системах країни. На концептуальному рівні визначено взаємну залежність функцій видатків бюджету від чинників, які на них впливають, а саме: функцій видатків у публічному управлінні, передусім, від ендогенних чинників та функцій видатків бюджету в економічній та соціальній системах країни, насамперед, від ендогенних чинників. У подальших наукових дослідженнях доцільно сорокусувати увагу на з'ясуванні 
природи взаємної залежності чинників, які впливають на бюджетні видатки, та їхніх функцій у країнах з ринковою економікою та демократичними відносинами в суспільстві.

\section{Список використаних джерел}

1. Масгрейв Р. А., Масгрейв П. Б. Государственные финансы: теория и практика : пер. с англ. М. : Бизнес Атлас, 2009. 716 c.

2. Walker M. L. Municipal expenditures. Baltimore : The Johns Hopkins Press. 1931.198 p.

3. Hackbar M., Ramsey J. R. The theory of the public sector budget: an economic perspective. In: Budget theory in the public sector: edited by A. Khan, W. B. Hildreth. London, 2002. 297 p.

4. Стігліи Дж. Е. Економіка державного сектору ; пер. з англ. А. Олійник, Р. Скільський. К. : Основи, 1998. 854 с.

5. Бланкарт Ш. Державні фрінанси в умовах демократії. Вступ до фрінансової науки ; пер. $з$ нім. С. І. Терещенко, О. О. Терещенка ; передмова та наук. редагування В. М. Федосова. К. : Либідь, 2000. $654 \mathrm{c}$.

6. Dorotinsky W. Implementing integrated financial management information systems: World Bank. 2003. URL : http://info.worldbank.org/etools/Bspan/ PresentationView.asp?PID=1014\&EID=502\#RM.

7. Campos E., Phadhan S. Budgetary institutions and expenditure outcomes. Binding governments to fiscal performance. Ed Campos Sanjay Pradhan. Washington: World Bank, 1996. 59 p.

8. Романенко О. Р. Фінанси : підручник. 4-е вид. К. : Центр учбової літератури, 2009. 312 c.

9. Исламгулов Р. Р. Бюджет и бюджетное регулирование в условиях федерализма. Уфа : Башкир. гос. ун-m, 2000. 88 c.

10. Корягін М. В. Сутність, ознаки та функції бюджету як економічної категорії. Науковий вісник НЛТУ України. 2010. Вип. 20.14. C. 205-209.

11. Пасічник Ю. В. Бюджетна система України та зарубіжних країн : навч. посіб. К. : Знання-Прес, 2002. 607 с.
12. Родионова В. М., Вавилов Ю. Я., Гончаренко Л. И. и др. Финансы. М. : Финансы и статистика, 1993. $400 \mathrm{c}$.

13. Розпутенко І. Державні видатки в перехідних економіках. К. : Вид-во Укр. акад. держ. упр. при Президентові України, 1998. 244 с.

14. Павлюк К. В. Теоретичні засади сутності бюджету і його функції. Наукові праці НДФІ. 2006. № 3 (36). С. 31-37.

15. Савчук Н. В. Бюджетні пріоритети України у контексті суспільного вибору : монографрія. К. : КНЕУ, 2014. 325 с.

16. Булгакова С. О., Василенко Л. І., Єрмоленко Л.В. та ін. Бюджетна система України : навч. посіб. ; за ред. С. О. Булгакової. К. : КНТЕУ, 2002. $288 \mathrm{c}$.

17. Захожай К. В. Роль, фрункції та завдання Державного бюджету України в сучасному суспільно-економічному просторі. Інвестиції: практика та досвід. 2017. № 20. С. 15-22.

18. Деркач Н. И., Гордеева Л. П. Бюджет и бюджетный прочесс на Украине. Днепропетровск : Пороги, 1995. 256 с.

19. Чухно А. А. Економічна теорія [у 2 m.]. T. 1. К. : ДННУ АФУ. 2010. 512 c.

20. Гордей О. Д. Соціальні аспекти бюджетної політики. Актуальні проблеми економіки. 2010. № 6 (108). С. 194-198.

21. Юрій С. І. Концептуальні засади сутності бюджету. Фінанси України. 2001. № 10. C. 3-10.

22. Ярошенко Ф. О. Бюджетна політика та економічне зростання: від моделей до реалій. Наукові праці НДФІ. 1996. Вип. 1-2 (24-25). C. 3-10.

23. Жаліло Я. А. Економічна стратегія держави: теорія, методологія, практика : монографрія. К. : НІСД, 2003. 368 c.

24. Ніколаєва О. М., Маглаперідзе А. С. Місцеві фрінанси : навчальний посібник. К. : Центр учбової літератури, 2013. 354 c.

25. Уманец О. П. Функции бюджета: cистематизация. Финансовая аналитика: проблемы и решения. 2012. № 28 (118). С. 18-28. 


\section{ДЕРЖАВНI ФІНАНСИ}

26. Словник іншомовних слів : уклад. : С. М. Морозов, Л. М. Шкарапута. К. : Наукова думка, 2000. - 680 с.

27. Словник української мови. Академічний тлумачний словник (1970-1980). URL : http:// sum.in.ua.

28. Oxford learners dictionary. URL : https:// www.oxfordlearnersdictionaries.com.

29. Экономический словарь. URL : https:// dic.academic.ru/dic.nsf/econ dict.

30. Robinson M., Last D. A basic model of performance-based budgeting. IMF. 2009. 12 p.

31. Якобсон Л. И. Государственный сектор экономики: экономическая теория и политика : учеб. для вузов. М. : ГУВШЭ, 2000. 367 с.

32. Сміт А. Добробут націй. Дослідження про природу та причини добробуту націй. К. : Port-Royal, 2001. 593 c.

33. Б'юкенен Дж. М., Масгрейв Р. А. Суспільні фрінанси і суспільний вибір: два протилежних бачення держави ; пер. з англ. К. : Вид. дім "КМ Академія", 2004. 175 с.

\section{References}

1. Musgrave, R. A, Musgrave, P. B. (2009). Gosudarstvennyie finansyi: Teoriya i praktika [Public finance in theory and practice] (Trans.). Moscow: Business Atlas [in Russian].

2. Walker, M. L. (1931). Municipal expenditures. Baltimore, The Johns Hopkins Press.

3. Hackbar, M., Ramsey, J. R. (2002). The theory of the public sector budget: An economic perspective. Khan, A., Hildreth, W.B. (Eds.). Budget theory in the public sector. London.

4. Stiglitz, J. E. (1998). Ekonomika derzhavnoho sektoru [Economics of the public sector] (Trans. Oliinyk, A., Skilskyi, R.). Kyiv: Osnovy [in Ukrainian].

5. Blankart, Ch. B. (2000). Derzhavni finansy v umovakh demokratii: Vstup do finansovoi nauky [Public finance in a democracy] (Trans. Tereshchenko, S.I., Tereshchenko, O.O.). Kyiv: Lybid [in Ukrainian].

6. Dorotinsky, W. (2003). Implementing integrated financial management information systems. World Bank Available at: http://info. worldbank.org/etools/Bspan/Presentation View. asp?PID=1014\&EID=502\#RM

7. Campos, E., Phadhan, S. (1996). Budgetary institutions and expenditure outcomes. Binding governments to fiscal performance. Washington: World Bank.

8. Romanenko, O.R. (2009). Finansy [Finance]. (4th ed.). Kyiv: Tsentr uchbovoi literatury [in Ukrainian].

9. Islamgulov, R. R. (2000). Byudzhet $i$ byudzhetnoe regulirovanie $v$ usloviyah federalizma [The budget and budget regulation in the conditions of federalism]. Ufa [in Russian].

10. Koriagin, M. V. (2010). Sutnist, oznaky ta funktsii biudzhetu yak ekonomichnoi katehorii [The essence, attributes and functions of the budget as an economic category]. Naukoviy visnyk NLTU - Scientific Bulletin of UNFU, 20 (14), 205-209 [in Ukrainian].

11. Pasichnyk, Yu. V. (2002). Biudzhetna systema Ukrainy ta zarubizhnykh krain [The budget system of Ukraine and the foreign countries]. Kyiv: Znannia-Press [in Ukrainian].

12. Rodionova, V. M., Vavilov, Yu. Ya., Goncharenko, L. I. (1993). Finansy [Finance]. Moscow: Finansy i statistika [in Russian].

13. Rozputenko, I. (1998). Derzhavni vydatky v perekhidnykh ekonomikakh [Public expenditures in transition economies]. Kyiv: Vydavnytstvo Ukrainskoi Akademii Derzhavnoho Upravlinnia pry Prezydentovi Ukrainy [in Ukrainian].

14. Pavliuk, K. V. (2006). Teoretychni zasady sutnosti biudzhetu i yoho funktsii [Theoretical foundations of the essence of budget and its functions]. Naukovi pratsi NDFI - Scientific Works of NDFI, 3 (36), 31-37 [in Ukrainian].

15. Savchuk, N. V. (2014). Biudzhetni priorytety Ukrainy u konteksti suspilnoho vyboru [Budget priorities of Ukraine in the context of public choice]. Kyiv: KNEU [in Ukrainian].

16. Bulhakova, S. O. (Ed.), Vasylenko, L. I., Yermolenko, L. V. (2002). Biudzhetna systema Ukrainy [The budget system of Ukraine]. Kyiv: Kyiv 


\section{ДЕРЖАВНІ ФIНАНСИ}

National University of Trade and Economics [in Ukrainian].

17. Zahozhai, K. V. (2017). Rol, funktsii ta zavdannia Derzhavnoho biudzhetu Ukrainy v suchasnomu suspilno-ekonomichnomu prostori [The role, functions and tasks of the State budget of Ukraine in the modern social and economic space]. Investytsii: praktyka ta dosvid - Investment: Practice and Experience, 20, 15-22 [in Ukrainian].

18. Derkach, N. I., Gordeeva, L. P. (1995). Byudzhet i byudzhetnyiy protsess na Ukraine [The budget and budget process in Ukraine]. Dnepropetrovsk: Porogi [in Russian].

19. Chuhno, A. A. (2010). Ekonomichna teoriia [Economic theory]. (Vol. 1). Kyiv: DNNU AFU [in Ukrainian].

20. Hordei, O. D. (2010). Sotsialni askpekty byudzhetnoi polityky [The social aspects of budget policy]. Aktualni problemy ekonomiky - Actual Problems of the Economy, 6(108), 194-198 [in Ukrainian].

21. Yurii, S. I. (2001). Kontseptualni zasady sutnosti byudzhetu [The conceptual foundations of the essence of budget]. Finansy Ukrainy - Finance of Ukraine, 10, 3-10 [in Ukrainian].

22. Yaroshenko, F. O. (1996). Byudzhetna polityka ta ekonomichne zrostannia: vid modelei do realii [Budget policy and economic growth: from models to realities]. Naukovi pratsi NDFI - Scientific Works of NDFI, 1-2 (24-25), 3-10 [in Ukrainian].

23. Zhalilo, Ya. A. (2003). Ekonomichna stratehiia derzhavy: teoriia, metodolohiia, practyka [The economic strategy of the state: theory, methodology, practice]. Kyiv: NISS [in Ukrainian].

24. Nikolaeva, O. M., Maglaperidze, A. S. (2013). Mistsevi finansy [Local finance]. Kyiv: Tsentr uchbovoi literatury [in Ukrainian].

25. Umanets, O. P. (2012). Funktsii byudzheta: sistematizatsiya [Functions of the budget: a systematization]. Finansovaya analitika: problemyi $i$ resheniya - Financial Analytics: Problems and Solutions, 28(118), 18-28 [in Russian].
26. Morozov, S.M., Skaraputa, L. M. (2000). Slovnyk inshomovnykh sliv [Dictionary of foreign words]. Kyiv: Naukova dumka [in Ukrainian].

27. Slovnyk ukrainskoi movy. Akademichnyi tlumachnyi slovnyk (1970-1980) [Dictionary of Ukrainian language. Academic explanatory dictionary (1970-1980)]. Available at: http://sum.in.ua.

28. Oxford learners dictionary. Available at https://www.oxfordlearnersdictionaries.com.

29. Ekonomicheskiy slovar [Economic dictionary]. Available at https://dic.academic.ru/dic.nsf/ econ dict.

30. Robinson, M., Last, D. (2009). A basic model of performance-based budgeting. IMF.

31. Yakobson, L, I. (2000). Gosudarstvennyiy sektor ekonomiki: ekonomicheskaya teoriya i politika [Public sector of the economy: economic theory and policy]. Moscow: HUVSE [in Russian].

32. Smith, A. (2001). Dobrobut natsii. Doslidzhennia pro pryrodu ta prychyny dobrobutu natsii [The wealth of nations. An inquiry into the nature and causes of the wealth of nations] (Trans.). Kyiv: Port-Royal [in Ukrainian].

33. Buchanan, J. M., Musgrave, R. A. (2004). Suspilni finansy i suspilnyi vybir: dva protylezhnykh bachennia derzhavy [Public finance and public choice: two contrasting visions of the state] (Trans.). Kyiv: Vyd. dim "KM Akademia” [in Ukrainian].

Стаття надійшла до редакції 03.03.2021 